For citation: Ekonomika regiona [Economy of Region]. - 2016. — Vol. 12, Issue 4. - pp. 1253-1262

doi $10.17059 / 2016-4-25$

UDC 65.012 .4

O. G. Rybakova, I. A. Kislukhina

Industrial University of Tyumen (Tyumen, Russian Federation; e-mail: olgryb@gmail.com)

\title{
ESTIMATION OF FLEXIBILITY OF AN ORGANIZATION ON THE GROUND OF THE CALCULATION OF PROFIT MARGIN RATE ${ }^{1}$
}

The article deals with the problem of the flexibility of an organization as the ability to adapt effectively to the external environment. The authors have identified and investigated different approaches to estimating the flexibility of an organization on the ground of flexibility grading, calculation of the general index of flexibility as well as the calculation of flexibility's ranking score. We have identified the advantages and disadvantages of these approaches. A new method of the estimation of an organization's flexibility on the ground of the calculation of relative profit margin has been developed. This method is the multifunctional assessment tool of enterprise's functionability in the current context of difficult and volatile economic environment. It allows in the early stage to identify negative trends in the production and financial figures and thus, it enables the organizational leadership to take steps in advance in order to avert a crisis in its activity. Keeping the profit margin at the same rate at the forced contraction of output, because of the negative impact of external factors, will confirm that the organization has adapted to the external environment and, therefore, it is flexible. The organization can be considered with margin rate beginning to low up to zero value as an organization with an insufficient level of flexibility that is at the "zone of crisis" and it is characterized by the depletion of reserved funds and reduction of current assets. Loss-maker is nonflexible and the presence of loss means that the organization has an evident sign of crisis and it can be bankrupt.

Keywords: flexible development of an organization, flexibility grading, crisis, adaptability to the external environment, flexible production system, flexibility ranking score, profit margin, relative profit margin, loss-maker, cumulative cost

\section{Introduction}

Fastest growing modern economics and business form complex, changeable and hardly forecasting conditions of commercial entities. Their effectiveness and even existence are mostly defined by their ability to adapt to the changeable market conditions.

There are many theories and approaches to the management of entities aimed at improving their effectiveness and preventing a crisis in their activity. One of the most effective approaches is the approach based on the flexible development of an organization. The purpose of the investigation is to create the universal method of estimating the flexibility of any organization (regardless of size, patterns of ownership and industry classification). The method is based on the determination of the organization's ability to function in the complex and unstable external environment that is their adaptability to the external conditions. We plan to carry out the investigation in two stages:

1. The first stage is the analysis of existing scientific theories on the flexible development of organization and the assessment of the efficiency of

\footnotetext{
${ }^{1}$ ( ) Rybakova O. G., Kislukhina I. A. Text. 2016.
}

the suggested methods of flexibility estimating on the following criteria:

- universality - applicability for the organization of different industry classification;

- ease of use - the possibility of mastering and using by corporate staff without involving any other specialists and experts;

- the amount of necessary data used in calculations - the minimum amount of monitoring characteristics of organization development needed for the calculation of flexibility index number and the possible minimum amount of the investigation stages.

2. The second stage is the development of estimation method of flexibility of an organization satisfying the above-mentioned criteria

\section{Methods}

The first stage of the investigation. In modern international economics and practice, there are many theories and methods of the enterprises' management that are focused on the improvement of theirs efficiency and preventing the crisis in their work. One of the most effective methods to prevent an economic crisis is the method based on the flexible development of an organization. 
The idea of flexibility is relatively new. In economic literature and business, it arose in the 70s of the 20th century. At first, the economists used the concept of flexibility in relation to the productive process. New ways and methods for the efficiency improvement of organization's activity have been seeking out in the context of rising business struggle. In the 70-80s of the 20th century, flexible production systems (FPS) went mainstream in all Largest Economies [1;2].

In the medium size lot production and the short run production, where it is needed the fast realignment of facilities for the new production batch, the application of FPS was extremely necessary. Since the objects of treatment were workpieces of different types, due to this fact, different types of systems appeared: the systems for automatic metal cutting, systems for sheet metal work, assembling systems and automatic factories (integrated industrial complexes) became the most varied systems [1].

In information and reference work "Flexible Production Systems of Japan", it is given the following definition of flexible production systems: "Flexible production system is a production system for metal cutting combining high productivity and realignment of facilities where the main objects of automatization are not only the treatment process but also inter-stage transport, facilities for manipulating with workpieces and means of control and regulation" [2, p. 3].

In the 80 s of the 20th century, the concept of flexibility in economics and management was treated in a more broad sense. Moreover, it was applied not only to the production process but also to the organization management in tote. It deals with the appearance of a new branch in theory and practice of management that is strategical management. I. Ansoff is the founder of strategical management. He characterizes it as "the variety of not only strategical decisions of management determining the long-term development of entity but as strategical actions providing fast response of an entity to the change of external market conditions which can force to apply strategical maneuver, reconsiderations of ends and readjustment of general drift [3, p. 42]. According to I. Ansoff, strategical management is "the system of entity management based on flexible emergency actions when many important tasks arise so fast that it is impossible to foresee them" [3, p. 48].

In strategical management, the concept of flexibility is fundamental and it is applied to all its parts: objects, tasks, plans, managerial decisions and so on [3; 4]. American scientists Arthur
A. Thompson and A.J. Strickland in their work "Grafting and Implementing Strategy" pointed out the necessity of creating flexible strategy containing the possibility of adaptation and noticed: "Company strategy is rarely so well thought out and made for a long term period that it can really withstand the test of time. Even the best plans have to foresee the possibility to adapt to the changing market conditions, consumer needs, strategical maneuvers of competitors, new arising possibilities and threats and unforeseen events" [4, p. 24].

At the end of the 20th and the beginning of the 21 st centuries, the flexibility of an organization i.e. its adaptability to the external environment has been associated with its feasibility. Wellknown American economist A. Elbing wrote: "The external environment of an organization is increasingly becoming the origin of problems for modern administrators. In principle, the administrators of the most important organizations of different kinds: business, educational and state are forced to pay attention to the fast-changing external environment and its impact on the internal structure of an organization" [5, p. 15].

The professor Y. Sheffi, the director of Transportation and Logistics Center of Massachusetts Institute of Technologies in his books "Viable Company: How to Improve the Reliability of Supply Chains and to Keep the Competitive Position" called the flexibility as an integral feature of all the processes in the company. According to his mind, production processes and fulfillment, corporate staff as well as relations with suppliers and consumers has to possess the flexibility. Y. Sheffi suggested making the flexibility the part of company organizational culture. According to his words "the most flexibility is reached when there are viable alternatives in any situations" Standardization of items, processes and production system making these elements interchangeable provide the free choice in the case of shortage. In the case of company failure, it can use the other spare items (or suppliers) or change the damaged components or use alternative processes or retool efforts" [6, p. 177].

At the last quarter of the 20th century scientific-technological advance (the emergence of new technologies, Internet, automation and so on), the processes of globalization in the major sector, science, culture and the development of institutional settings towards the democratization, humanization and informational support of the society formed the "new reality". This "new reality" was much more different from "the conventional wisdom of reality" as a part of the present model of 
management. So as a result of these processes, a great number of scientific works on the problem of management model between 20th and 21st centuries appeared $[7 ; 8 ; 9 ; 10 ; 11$ and others].

According to P. Druker - "since then it started the deep study of the management theory-this event should be referred to the beginning of the $30 \mathrm{~s}$ - the most of the scientists, writers and experts held to the two systems of conceptualizations about management. The first system is based on the management science and it follows the concepts: 1) management is the management of business; 2) there is - or there must be-one correct organizational framework; 3 ) there is-or there must be-one correct staff management method. The second system is based on management practical activity and it follows the concepts: 1 ) technologies, markets and final usage are given; 2) the management sphere of action stands well at law; 3) management is concentrated on the internal core competence of an organization; 4) being within state borders economics is "natural ecological environment" of business activity and management [8, p. 18].

"Long enough - P. Drucker notices - at least until the beginning of the 80 s - nearly all these ideas were consistent with reality and let to found on them in practical activity... To the present time, they are absolutely run their course and they give us laugh rather than respect. Today they are so remote from reality that they thwart progress and what is worse they interfere with practical activity. The fact is that the reality is rapidly changing and becoming fewer alike that ideas about it which there have been in management. So today is the day, when we should rethink them and try to define the new concepts which will revive the science and practice of management" [8, p. 18-19].

In the context of management paradigm shift, the concept of flexibility took another development. As N. Pfeling the president of consulting company "Meta Management Group", the director of world famous "Business Roundtable" and "Beyond the Budgets" notes: "Economics and society have changed but as for the methods and criteria of management, which we use in direction and management, they have stayed put. Setting fixed ends, personnel ranking, so called the fee earnings policy on the ground of efficiency, budgets, comparisons "plan-fact", micromanagement on the turn of administration - all of these are well-entrenched beliefs. But do they match the spirit of our time?" [12, p. 9].

In his book "Management on the Ground of Flexible Objectives. Out of Budgeting: How to
Outperform Competitor in the XXI Century" [12] $N$. Pfeling writes about the necessity to abandon the fixed ends because they are nonrealistic and even dangerous for a business to the relative ends having flexibility that is the ability to adjust to the external changes. "Imagine $-\mathrm{N}$. Pfeling talks - that before the beginning of the next race "Formula-1" one of the racers gets from his coach the following instruction: each lap of the competition he must run within the definite time which he, the coach, has calculated on the ground of methodic and empiric observations and thought them "to be optimal", ... the racer should keep strictly the stipulated time and shouldn't adjust to the results and behavior of the other racers, car reliability or the other competitors. It is impossible to imagine such situation in reality... Such behavior would be not only clumsy but also dangerous as external conditions on the lap are impossible to predict or control. The irony of this is that it is quite an ordinary way of management for the most enterprises. Regardless of all reasonable arguments and in spite of that actual and flexible ends are natural and the only closely knit form of demand to company performance in a competitive climate and dynamic environment we manage an entrepot with the help of unnecessary and dangerous fixed ends which are far from reality" [12, p. 69]. "Relative ends are flexible they adjust to the changes automatically. They are not fixed and they should not obligatory have numerical expression... They come to an existence conversationally and during searching consensus on general nature of business. A chief should not give such end in classical ideas of this process and it should be not given... through the hierarchy. It can appear without hierarchy and government. Indeed after they adopted the decision about suitable criteria of company performance (indicator) and defined relative target it is practically impossible to say later on ... that the end was chosen incorrectly. In the future, one can define quite clearly how it is necessary to evaluate results. This assessment, however, happens not in the light of previously established expectations but in the light of all internal and external expectation factors"- concluded N. Pfeling [12, p. 110-111].

In the Russian economical literature and business, the appearance of the concept of "flexible development of an organization" deals with economic reforms in the 90s of the 20th century. These economic reforms identified the problem of the former soviet state entities to work effectively in the conditions of market economy and it set off the necessity to adapt them to the new condi- 
tions of economic management. According to the opinion of many economists $[13 ; 14 ; 15$ and others], the problem of flexible development of an organization has become especially urgent for the Russian business as far as domestic organization had to adapt to the modern difficult and extremely unstable external conditions but they do not have any experience in the conditions of market economy at all. Many works of native economists are devoted to the problems of the adaptation of Russian enterprises. We can distinguish such works as "Adaptation of an Industrial Firm: Theory and Practice" written by I.B. Gurkov [14], "About Russian Business Enterprises Survival Strategy in Economic Rebound" by V.I. Marshev [15]; “The Adaptation Strategies of Industrial Enterprises" by I.B. Gurkov [16]; "Business Enterprises in the Conditions of Market Reform: New Behaviour Model" by E.S. Nabiulina [17]; "Enterprise management in reformed Russian economics" by I.E. Risin [18]; “Transitional Behaviour Model of Russian Industrial Enterprises” by T. Dolgopyatova [19] among them. According to the definition of I.B. Gurkov: "adaptation is the enterprise maintenance in the conditions of the external environment changing as a result of changed relations character with the external environment and transformation of the inner structure of an enterprise" [14, p. 9].

The analysis of different determinations of the concept "flexibility" gives us the possibility to make a conclusion that the general sense of all these determinations is as follows: one may understand flexibility as the ability of an enterprise to adapt to external environment. Therefore, the flexible production systems permit to adapt the production to the clients' inquiries and thus, they satisfy changing demand better. In the other words, flexible production technologies are the means of the reconstruction of the internal environment of an enterprise accordingly to the changing external environment. Actually, one should solve the same problem in the framework of strategical management only the process of enterprise adaptability is distinguished more widely. The strategical management determines the enterprise adaptability not only in terms of the flexible production technology but also in terms of the flexibility of strategical ends and objects, strategical management decisions, business development plans and so on. Adaptability of Russian business enterprises to the market economy in the conditions of transitional economy supposes to form flexible management system, flexible ends and objectives and flexible production process aimed the client of an enterprise.
Therefore, under the flexibility of an organization, we will understand the ability of an organization to adapt to the external environment in time and to react to its changes in a proper way.

The adaptability of an organization to the unstable external environment keeping for a long period of time we will call the flexible development of an organization.

The flexibility is a vital feature of an organization. It permits the organization to function and develop in the context of difficult changeable and the poorly predictable external environment. In this regard, there is a question: how can we measure and control this very feature of an organization?

In modern management theory, there are many different points of view on the problem of estimating the flexibility of an organization. We can define three main approaches to the estimating of a flexibility used by Russian and foreign scientists:

- the estimating of a flexibility on the ground on flexibility grading;

- the estimating of a flexibility on the ground of the general index of flexibility;

- calculating of flexibility's ranking score.

For example, Russian economist V.N. Vasilyev and T.G. Sadovskaya suggest using special grading for the estimation of flexibility. This grading permits to identify to what type of flexibility belongs the organization. V.N. Vasilyev and T.G. Sadovskaya define four types of flexibility [20, c. 32]:

- The first type of flexibility is - hard production method having manufacturing equipment for making only one item.

- The second type of flexibility is - readjustable production method. When change some parts or reconfiguration of the equipment. it can be used for manufacturing a new item or a strongly fixed product group.

- The third type of flexibility is - readjustable engineering procedures and appropriate equipment for simultaneous manufacturing of product group.

- The fourth type of flexibility is - flexible production method and the equipment adjusted for the sophisticated automation.

We suppose that the approach to the definition of flexibility on the ground of grading is the most suitable for the estimating the production flexibility as far as we can classify the flexible production systems in accordance with the rate of equipment readjustment and the level of automation of production processes. However, the usage of this approach when estimating the flexibility of an organization as an ability to adapt to the ex- 
ternal environment has a number of major disadvantages. As professor V.N. Samochkin notes that the main disadvantages of the approach to the determination of flexibility on the ground of grading are "the discretisation of the flexibility meanings, the difficulty of building the dependences on several contradictory factors and subjectivity in choosing the factors" [21, p. 16].

V.N. Samochkin developed another method of estimating the flexibility of an organization on the ground of calculation the flexible general index. His scientific work "Flexible Development of an Organization: Analysis and Planning” [21] is a complex theoretical and methodological investigation and hands-on management of diagnostics and planning of flexible development of an organization in the context of the unstable and unfriendly external environment. In this paper, the author suggests the methodology for estimating of an organization economic status through the flexibility model and the comparison of the received data with "sufficient". According to his words, regulatory (sufficient) data were identified through statistical data processing of Russian enterprises. V.N. Samochkin gives the following definition of the organization flexibility: "organization flexibility is an organization ability to get the necessary result permitting it to put into production the obligated amount of items which can be marketable without a fundamental change of basic production assets. In exchange, they permit to get needed result providing survival and development of a company in future". [21, p. 19]. V.N. Samochkin defined two main criterion of the definition of organization flexibility [21, p. 19]:

- enterprise performance result at present (result of renewal);

- enterprise relation with the external environment that is its ability to plan and predict the process of its development for renewal (ability of renewal).

V.N. Samochkin developed the main formula of estimating the model of organization's flexibility (formula 1) [21, p. 39].

To our mind, the approach suggested by V.N. Samochkin has some advantages. Among them are comprehensiveness and objectivity of estimation and correlation with Russian economic conditions. But it has such disadvantages as difficulty and multiple stages of calculations, the necessity of collection and organization large amount of data, the lack of allowing for industry-specific and regional peculiarities of management and the impossibility of use in the context of enterprise diversification of activity. result for renewal (1st part)

$$
\begin{gathered}
F=f\left(S_{r}, A_{r}\right)=f[M P / P S P S / A A / \mathrm{OA} \\
\text { ability to renewal (2nd part) } \\
\left.P R / M P, \mathrm{~T}_{1} / \mathrm{T}_{\mathrm{p}} \mathrm{n}\right]= \\
=f\left[\left(R_{s} A L P M\right),\left(C_{r} n\right)\right]=f\left[S_{r}, N\right],
\end{gathered}
$$

where $F$-criteria of estimation the flexibility of an organization; $S_{r}=\left(R_{s} A L P M\right)$ - strength of an organization to renewal (economic strength);

$R_{\mathrm{s}}=M_{\mathrm{P}} / P S-$ return on sales;

$A=P S / A-$ assets turnover;

$L=A / O A-$ leverage;

$P M=P R / M_{P}-$ profit margin for renewal;

$M_{P}$ - margin of profit;

$P S$ - products sold;

$A$-assets;

$O A$ - owned assets;

$P R$ - profit for renewal;

$A r=C r n=N-$ ability of an organization to renewal (calculated number of items in lead time); $C r=T_{l} / T_{p}-$ coefficient of renewal;

$T_{1}$-lead time;

$T_{p}$-production time;

$n$-nomenclature (systematic classification of products manufactured by organization).

Western economists T. Whellen and D. Hunger suggest estimating the adaptability (flexibility) of an organization by means of identifying the level of its reaction to new possibilities and threats of the external environment. [22]. For this, T. Whellen and D. Hunger advise to use particular form "External Strategic Factors Analysis Summary"-EFAS which permits to generalize the data of SWOT-external strategic factors analysis controlling for the importance of these data for organization future. Let us examine the methodology of estimating flexibility of an organization suggested by T. Whellen and D. Hunger using the example of "Maytag" corporation (table 1) [22]:

1. There are 5-10 possibilities and the same number of threats in the first column

2. Each factor is attributed weight value (column 2) from one (the most important) to zero (insignificant) on the ground of the estimation of the possible impact of this factor on the organization strategic position. Total weight should be equal to one.

3. Each factor is estimated on five-point grading scale (column 3): "five" - perfect, "four" - upper medium, "three" - medium, "two"-lower medium, "one"-insignificant. The estimates are based on the peculiar reaction of an organization on this factor.

4. The weighted values of each factor are identified by multiplying its weight by an estimate and calculate the total weighted value for the given organization (column 4). Total estimate (defined on 
The EFAS Form of Maytag Corporation

\begin{tabular}{|c|c|c|c|}
\hline External strategic factors & Weight & Estimate & $\begin{array}{l}\text { Weighted } \\
\text { Estimate }\end{array}$ \\
\hline $\begin{array}{l}\text { Possibilities: } \\
\text { 1. Economic integration of Europe } \\
\text { 2. Good demographic situation } \\
\text { 3. Economic development of Asia } \\
\text { 4. Eastern European markets } \\
\text { 5. Development of superstore net } \\
\text { Threats: } \\
\text { 1. The strengthening of government control } \\
\text { 2. Business struggles on the internal market } \\
\text { 3. The strong global position of the Electrolux firm } \\
\text { 4. Technical innovation of the Fuzzy firm } \\
\text { 5. Supposed falling-off production }\end{array}$ & $\begin{array}{l}0,20 \\
0,10 \\
0,05 \\
0,05 \\
0,10 \\
\\
0,10 \\
0,10 \\
0,15 \\
0,05 \\
0,10\end{array}$ & $\begin{array}{l}4 \\
5 \\
1 \\
2 \\
2 \\
\\
4 \\
4 \\
3 \\
1 \\
2\end{array}$ & $\begin{array}{l}0,80 \\
0,50 \\
0,05 \\
0,10 \\
0,20 \\
\\
0,40 \\
0,40 \\
0,45 \\
0,05 \\
0,20\end{array}$ \\
\hline Total estimate: & 1,00 & & 3,15 \\
\hline
\end{tabular}

five-point grading scale as well as the estimate of each factor) points to the degree of organization reaction on the external environment factors. In the given example, the estimate is 3,15 . It means that the organization's reaction is at the medium level.

To our mind, the advantages of estimating the flexibility method suggested by $\mathrm{T}$. Whellen and D. Hunger are its elegance and applicability for any type of organization. Although, this method has some important disadvantages such as:

1. High level of subjectivity is at all stages of estimating flexibility of an organization. The weight of each factor (the possible force of impact) and estimate (the level of organization's reaction of the particular factor) are determined rather subjectively and depended on the experts making them.

2. The specialty of criteria of estimating flexibility of an organization and the absence of universal generalized criteria. This method of estimating the flexibility of an organization supposes forming the list of valued factors (possibilities and threats) on the ground of SWOT-analysis made for a particular organization. It means that every organization will have its own list of possibilities and threats. The force of impact of these factors and the level of reaction of an organization are also determined for a particular event as far as the factors of external environment influence on different organizations in its own way.

3. A lack of comparability of the rating system of an organization's flexibility. Different aspects and threats will appear for organizations being in different market conditions, occupying different in size volume market and having different production output and nomenclature of turn out products. In such case, the reaction of these organizations will be not comparable as far as the reactions of two organizations expressed in the same terms will not mean that they have an equal ability to adaptability that is equally flexible. Like the same organization being in different periods and in different economic conditions will have to react to different external conditions. Consequently, if the index of reaction level of an organization increases from 3,10 to 3,15 , this fact will be not the direct evidence of increasing its level of flexibility.

The above-mentioned three approaches do not limit the possibilities of estimating the flexibility of an organization. All the more so every approach has its own disadvantages and requires improvement.

The second stage of the investigation. Let develop a new method for estimating the flexibility of an organization taking into account its dependence on the external environment as well as the disadvantages of above-mentioned methods.

In the most cases as practice shows, the influence of external environment causes the increase of cumulate costs of the organization. For example, the increase of electricity tariffs influences on variable costs increasing the cost of energy usage in the productive process. In addition, it influences the increase of constant costs causing the increase of the cost of energy usage in offices, warehoused and illuminated a land area of an organization and so on. In addition to the above, the output of products will decrease if the organizational leadership fail to optimize spending pattern, get additional borrowed proceeds or increase sell-in price. The decrease of the products output is the result of changing in process costs structure. That is the ratio growth of energy usage (in value terms), which causes the forced curtailment of expenses on materials, collecting sets, spare parts for machinery and the other elements of current assets providing the process of production. 
It is very difficult to keep the absolute profit margin at the same level during the decrease of products output. Although, it is possible to keep relative profit margin $M_{p}$ as a ratio of full cost $M_{p}=\frac{P}{C}$ or as a percentage of it $M_{P}=\frac{P}{C} \times 100 \%$.

Let us define the dependence of production output $\mathrm{K}$ from the cumulative costs of an organization at fixed level of relative profit margin as a percentage of full cost $(5 \%, 15 \%, 25 \%, 40 \%$, $50 \%, 60 \%$ и $100 \%$ ) on the ground of the adapted method of economic and mathematic modelling of S. A. Zhdanov [23]. This method was adapted for the estimation of the organization's flexibility and demonstrated the high efficiency, reliability and certainty of obtained results. Let us introduce the following notations: $P$-absolute profit margin for the period of time under review; $C$-products full cost (at products output of $K$ units); $K$-output of products; $I_{v a r}$-variable costs for the unite of output; $R$-unit cost; $I_{\text {const }}$-constant expenses of an organization for the period of time under review; $\frac{I_{\text {const }}}{I_{\text {var }}}$-relative constant expenses; $\frac{R}{I_{\text {var }}}$-relative cost; $M_{p}$-relative standard profit margin rate is given in the fractional form $M_{p}=\frac{P}{C}$.

Let us carry out the proof of the analytical criterion $M_{p}$ and reveal numerator and denominator parameters in the formula

$$
\begin{gathered}
P=K\left(R-I_{\text {var }}\right)-I_{\text {const }}, \\
C=K I_{\text {var }}+I_{\text {const }} .
\end{gathered}
$$

Let us substitute the value of exponents $P$ and $C$ in the formula $M_{p}=\frac{P}{C}$ and we get:

$$
M_{p}=\frac{K\left(R-I_{\text {var }}\right)-I_{\text {const }}}{K I_{\text {var }}+I_{\text {const }}} .
$$

Let us transform the deduced formula:

$$
\begin{gathered}
K I_{\text {var }} M_{p}+I_{\text {const }} M_{p}=K R-K I_{\text {var }}-I_{\text {const }}, \\
K\left(R-I_{\text {var }}\left(1+M_{p}\right)\right)=I_{\text {const }}\left(1+M_{p}\right) .
\end{gathered}
$$

Solving this equation relatively $K$ we get:

$$
K=\frac{I_{\text {const }}\left(1+M_{p}\right)}{R-I_{\text {var }}\left(1+M_{p}\right)} .
$$
have:

Dividing numerator and denominator by $I_{v a r}$ we

$$
K=\frac{\frac{I_{\text {const }}}{I_{\text {var }}}\left(1+M_{p}\right)}{\frac{R}{I_{\text {var }}}-\left(1+M_{p}\right)},
$$

Introducing the data value: $\frac{I_{\text {const }}}{I_{\text {var }}}=\gamma$ and $\frac{R}{I_{\text {var }}}=\beta$ we get:

$$
K=\frac{\gamma\left(1+M_{p}\right)}{\beta-\left(1+M_{p}\right)}=\frac{\gamma}{\frac{\beta}{1+M_{p}}-1} .
$$

As can be seen from the above, general link of $K$ output of products from the cumulative costs of an organization at fixed level of relative profit margin is as follows:

$$
K=\frac{\gamma}{\frac{\beta}{1+M_{p}}-1} .
$$

It follows that when profit margin rate is $100 \%$ of full cost, $K$ output of products will be calculated in this way:

$$
K=\frac{\gamma}{\frac{\beta}{1+1}-1}=\frac{\gamma}{0,5 \beta-1} .
$$

Accordingly:

$K=\frac{\gamma}{0,95 \beta-1}-$ when profit margin rate is $5 \%$ of

$K=\frac{\gamma}{0,87 \beta-1}-$ when profit margin rate is $15 \%$

$K=\frac{\gamma}{0,8 \beta-1}-$ when profit margin rate is $25 \%$

$K=\frac{\gamma}{0,71 \beta-1}-$ when profit margin rate is $40 \%$ of

$K=\frac{\gamma}{0,67 \beta-1}-$ when profit margin rate is $50 \%$

$K=\frac{\gamma}{0,625 \beta-1}-$ when profit margin rate is $60 \%$

$K=\frac{\gamma}{\beta-1}-\begin{gathered}\text { when break-even condition of produc- } \\ \text { tion. }\end{gathered}$

Making a profit equal to full cost (100\% from full cost) is rather a difficult task as far as it needs

$K$ the large output of products or $\beta=\frac{R}{I_{v a r}}$ high relative cost (as it is seen from formula 5 , it is possible only when $\beta>2$ ).

In the case, when it is impossible to provide a high level of products output and it begins to decrease because of external environment factors. Moreover, there is no possibility to increase producer's prices. Then in order to keep the standard 
profit margin rate as in ratio from full cost $M_{p}=\frac{P}{C}$ at the same level, one should try to decrease the level of constant expenses with the help of transferring available capacities on the output of other products, letting on hire some parts of facilities and buildings, selling unused equipment, decreasing the spending on non-business purposes and reducing a part of staff.

The decrease of constant expenses on the value $\Delta I_{\text {const }}$ relatively to the decrease of products output $\Delta K$, we can introduce as follows:

$$
\Delta I_{\text {const }}=\Delta K\left(\frac{R}{1+M_{p}-I_{v a r}}\right) .
$$

From the formula (13), it follows that for keeping existing profit margin rate $M_{p}$ when decreasing the output of products on the value $\Delta K$, it is necessary to decrease the level of constant expenses on the value $\Delta I_{\text {const }}$, in proportion to the decrease of factory load in accordance with the formula (13). In addition, it also the decrease of total variable expenses on the value $\Delta K \times I_{v a r}$ occurs.

Keeping the profit margin rate of an organization $-M_{p}$ at the same level with forced decrease of production output $-K$ as the result of the negative impact of external factors will indicate that an organization has adopted to the external environment and therefore it is flexible.

\section{Results}

As the result, the condition of the flexibility of an organization we can describe with the following formula:

$$
M_{p}=\frac{P}{C}=\text { const, when } K_{\min } \leq K_{j}<K_{0},
$$

where $K_{0}-$ standard output of products; $K_{j}-$ new level of output of products corrected under the influence of external environment factors; $K_{\min }-$ minimum output of products providing break-even condition.

It follows that an organization with profit margin $-M_{p}$ when decreasing the output of products $-\stackrel{p}{K}$ begins to decrease until zero value $-M_{p} \geq 0$, we can define as an organization with an imperfect level of flexibility. This organization is coming in the "zone of crisis" characterized by depletion of emergency reserve funds and a decrease in floating assets. In the circumstances, it is necessary to reshape the organization in order to adapt it to the new business trends and to restore the profit margin at the same level. Otherwise, this organization is under the threat of financial insolvency. The timing of the finan- cial insolvency we may calculate on the basis of the dynamics of the profit margin decrease and the moment of coming into "the zone of negative profit". The condition of the flexibility of an organization's decrease we can describe by the following formula:

$$
0 \leq M_{p j}<M_{p 0} \text {, when } K_{\min } \leq K_{j}<K_{0},
$$

where $K_{0}$-standard output of products; $K_{j}-$ new level of output of products corrected under the influence of external environment factors; $K_{\min }$-minimum output of products providing break-even condition; $M_{p 0}$-standard profit margin; $M_{p j}-$ new level of the organization profit margin.

For the loss-makers, we may also define the general dependence of output of products $K$ from cumulative costs of an organization at fixed level of relative losses $M_{\text {loss }}$ as a ratio or as a percentage of full cost. The formula will be as follows:

$$
K=\frac{\gamma}{\frac{\beta}{1-M_{\text {loss }}}-1} .
$$

Let us define the dependence of output products $K$ from the cumulative costs of an organization at fixed level of relative losses $M_{\text {loss }}$ as a percentage of the full cost of products $(10 \%, 20 \%$, $30 \%, 40 \%, 50 \%)$.

$$
K=\frac{\gamma}{1,11 \beta-1}-\text { when loss ratio is } 10 \% \text { of full }
$$

$K=\frac{\gamma}{1,25 \beta-1}-$ when loss ratio is $20 \%$ of full

$K=\frac{\gamma}{1,43 \beta-1}-$ when loss ratio is $30 \%$ of full

$K=\frac{\gamma}{1,67 \beta-1}-$ when loss ratio is $40 \%$ of full

$K=\frac{\gamma}{2 \beta-1}-\begin{gathered}\text { when loss ratio is } 50 \% \text { of full } \\ \text { cost. }\end{gathered}$

Loss-maker is nonflexible. The presence of losses is a sign that the crisis in the work of organization has brightly expressed character and it brings the direct threat of bankruptcy. As a rule, such organization has no reserve funds and there is a hard deficit of floating assets. For the lossmaker, it is necessary to introduce the regime of anti-crisis management and take urgent measures in order to stabilize its financial status. If the anti-crisis measures would not be taken so an organization will step in "the zone of financial insolvency". According to the Federal Low, which is now in force in Russia "About bankruptcy” № 127-FZ d. 
d. 26.10.2002 the organization has three months left till bringing the matter before the court with the documents claiming out the adjudication of bankruptcy of the debtor.

\section{Discussion}

To our mind, the method of estimating the flexibility of an organization on the ground of the calculation of relative profit margin is universal means of estimating the ability of an organization to work in the modern conditions of difficult and unstable external environment. The given method lets to reveal negative tendencies in the dynamics of production and financial data at the early stage. Therefore, it gives the possibility to the administration to take measures in order to prevent crisis in the activity of organization.

\section{References}

1. Fedotov, A. I. (Ed.). (1989). Gibkie proizvodstvennye sistemy sborki [Flexible production assembly systems]. Leningrad: Engineering. Leningradskoye otdelenie Publ., 349.

2. Lishchinsky, A. L. (Ed.). Gibkie proizvodstvennyye sistemy Yaponii [Flexible production systems of Japan]. Trans. from Japanese. Moscow: Mashinostroenie Publ., 232.

3. Ansoff, I. (1989). Strategicheskoe upravlenie [Strategical management]. Short translation from English. Moscow: Ekonomika Publ., 519.

4. Tompson, A. A. \& Striklend, A. J. (1998). Strategicheskiy menedzhment: iskusstvo razrabotki i realizatsii strategii [Crafting \& Executing Strategy: The Quest for Competitive Advantage]. Trans. from English. Moscow: Banki i birzhi Publ.; YuNITI Publ., 576.

5. Elbing, A. O. (1974). On the Applicability of Environmental Models. N. J.: Prentice-Hall, 283.

6. Sheffi, Y. (2006). Zhiznestoykoye predpriyatie: kak povysit nadyozhnost tsepochki postavok i sokhranit konkurentnoye preimushchestvo [Viable company: how to improve the reliability of supply chains and to keep the competitive position]. Trans. from English. Moscow: Alpina Business Books Publ., 301.

7. Byk, F. L. \& Kitushin, V. G. (2007). Ponyatiynye aspekty novoy paradigmy upravleniya [Conceptual aspects of new management paradigm]. Menedzhment $v$ Rossii i za rubezhom [Management in Russia and abroad], 5, 3-8.

8. Druker, P. F. (2000). Zadachi menedzhmenta $v$ XXI veke [The problems of management it the 21st century]. Trans. from English. Moscow: Wiliams Publ., 272.

9. Klok, K. \& Goldsmit, J. (2004). Konets menedzhmenta i stanovlenie organizatsionnoy demokratii [The end of management and formation of organizational democracy]. St. Petersburg: Piter Publ., 368.

10. Kovi, S. R. (2008). Liderstvo, osnovannoye na printsipakh [The leadership based on rules]. Trans. from English by P. Samsonov. Moscow: Alpina Business Books Publ., 312.

11. Sergeev, A. L. (2005). Instituty upravlencheskoy paradigmy [The institutions of management paradigm]. Menedzhment $v$ Rossii i za rubezhom [Management in Russia and abroad], 2, 55-66.

12. Pfeling, N. (200). Upravlenie na osnove gibkikh tseley. Vne byudzhetirovaniya: kak prevzoyti konkurentov $v$ XXI veke [Management on the ground of flexible objectives. Out of budgeting: how to outperform competitor in the 21st century]. Trans. from German by a. Druzenko. Moscow: Belyy gorod Publ., 280.

13. Biryukov, P. A. \& Kuzmina, M. V. (2000). Problema adaptatsii lesozagotovitelnykh predpriyatiy v rynochnoy srede [The problem of adaptation of wood cutting companies in market environment]. Lesnoy zhurnal [Forest journal], 5-6, $62-65$.

14. Gurkov, I. B. (1997). Adaptatsiya promyshlennoy firmy: teoriya i praktika [Adaptation of an industrial firm: theory and practice]. Moscow: VShE Publ., 134.

15. Marshev, V. I. \& Ayvazyan, Z. S. (1996). O strategii vyzhivaniya rossiyskikh predpriyatiy v perekhodnyy period (Opyt upravlencheskogo konsultirovaniya) [About Russian business enterprises survival strategy in economic rebound (the experience of management consulting)]. Moscow: Dialog-MGU Publ., 51.

16. Gurkov, I. B. (1994). Strategii adaptatsii promyshlennykh predpriyatiy [The adaptation strategies of industrial enterprises]. Rossiyskiy ekonomicheskiy zhurnal [Russian economics journal], 2, 3-11.

17. Nabiulina, E. S. (1993). Predpriyatiya $v$ usloviyakh reformy: novyye modeli povedeniya [Business enterprises in the conditions of market reform: new behaviour model]. Moscow: Ekspertnyy institut RSPP Publ., 48.

18. Risin, I. E. (1996). Upravlenie predpriyatiem v reformiruemoy ekonomike Rossii [Enterprise management in reformed Russian economics]. Voronezh: VGU Publ., 109.

19. Dolgopyatova, T. (1996). Perekhodnaya model povedeniya rossiyskikh promyshlennykh predpriyatiy [Enterprise management in reformed Russian economics]. Voprosy ekonomiki [Question of economy], 11, 119-130.

20. Vasilyev, V. N. \& Sadovskaya, T. G. (1988). Organizatsionno-ekonomicheskie osnovy gibkogo proizvodstva [Organizational and economical grounds of flexible production]. Moscow: Vysshaya shkola Publ., 272.

21. Samochkin, V. N. (2000). Gibkoye razvitie predpriyatiya: analiz i planirovanie [Flexible development of an organization: analysis and planning]. 2-nd ed., corrected and added. Moscow: Delo Publ., 376.

22. Whellen, T. \& Hunger, D. (1992). Strategic Management \& Business Policy [Strategic management \& business policy]. N.Y.: Addison-Wesley Publishing Company, Inc., 326. 
23. Zhdanov, S. A. (2001). Etalony normalnogo i krizisnogo funktsionirovaniya predpriyatiy [Samples of standard and crisis enterprises performance]. Moscow: Editorial URSS, 216.

\section{Authors}

Olga Gennadevna Rybakova - PhD in Cultural Studies, Associate Professor, Industrial University of Tyumen (2/P, Lenina St., Nizhnevartovsk, Khanty-Mansi Autonomous Area - Yugra, 628600, Russian Federation; e-mail: olgryb@gmail. com).

Irina Anatolyevna Kislykhina-Doctor of Economics, Professor, Department of Humanities and Economics and Natural Sciences, Industrial University of Tyumen (2/P, Lenina St., Nizhnevartovsk, Khanty-Mansi Autonomous Area -Yugra, 628600, Russian Federation; e-mail: irina_for@mail.ru). 